\title{
To see or not to see: Profesní vidění budoucích učitelů anglického jazyka a budoucích učitelů pro 1. stupeň se specializací na anglický jazyk ${ }^{1}$
}

\author{
Klára Uličná
}

Univerzita Karlova, Pedagogická fakulta, Katedra anglického jazyka a literatury

Redakci zasláno 21. 12. 2016 / upravená verze obdržena 8. 3. 2017 /

k uveřejnění přijato 10.3. 2017

\begin{abstract}
Abstrakt: Cílem empirické studie je prozkoumat profesní vidění budoucích učitelů anglického jazyka. Pozornost je věnována především tomu, jakých doménově obecných i doménově specifických jevů si studenti učitelství všímají, ovšem sledována je také oblast uvažování založeného na vědění, tedy jak nad identifikovanými jevy přemýšlejí. Zaměřujeme se na rozdíl povahy vybraných aspektů profesního vidění mezi budoucími učiteli anglického jazyka pro 2 . stupeň základní školy a střední školy a budoucími učiteli pro 1 . stupeň se specializací na anglický jazyk. V první části textu vymezíme koncept profesního vidění v kontextu přípravného vzdělávání učitelů. Další část je věnována samotnému výzkumnému šetření, a to obsahové analýze nestrukturovaných reflexí studentů pořízených na základě sledování videozáznamu stejné výuky anglického jazyka na základní škole. Výsledky studie naznačují, že mezi studenty učitelství anglického jazyka pro 2. stupeň základní školy a střední školy (AJ2) a budoucími učiteli pro 1. stupeň se specializací na anglický jazyk (AJ1) je statisticky signifikantní rozdíl ve všímání si kategorie žák. Tato kategorie je následně podrobena hlubší analýze s cílem odhalit, v jakých aspektech se obě zkoumané skupiny studentů liší. Ukazuje se, že se tak děje především ve věnování pozornosti oborovým a oborovědidaktickým aspektům výuky (AJ2) a klimatu třídy (AJ1) a v uvažování nad viděným prostřednictvím hodnocení (AJ1) a interpretace (AJ2).
\end{abstract}

Klíčová slova: profesní vidění, všímání si, uvažování založené na vědění, přípravné vzdělávání učitelů anglického jazyka, video

Všímati si okolí, to chce mít zrak sokolí... (Zdeněk Joukl, Všímavost)

1 Tato studie byla podpořena projektem PRVOUK P15 Škola a učitelská profese v kontextu rostoucích nároků na vzdělávání, Pedagogická fakulta Univerzity Karlovy.

Ráda bych na tomto místě rovněž poděkovala recenzentům za jejich cenné připomínky. 
V rámci přípravného vzdělávání učitelů je nutné rozvíjet široké spektrum profesních znalostí a dovedností i schopnosti reflexe. Studenti učitelství bývají v České republice standardně připravováni v oblasti obecného základu, tj. pedagogických a psychologických disciplín, v oblasti oborové a v neposlední řadě pak v oborových didaktikách. Kromě teoretické přípravy tvoří integrální součást přípravného vzdělávání učitelů i praktická příprava, která bývá realizována prostřednictvím výukové praxe ve školách. Propojení teoretické a praktické složky přípravného vzdělávání může být realizováno rovněž např. prostřednictvím tzv. náslechové praxe, tedy pozorováním reálné výuky ve školách či pozorováním videozáznamů reálné výuky.

Pozorování výuky, at' již vlastní, či cizí, je jednou z klíčových technik podporujících profesní rozvoj učitelů. Jedná se o reflektivní techniku, která umožňuje hlubší porozumění procesům vyučování a učení, potažmo pak ovlivňuje vlastní výukovou praxi (Janík et al., 2011). Pozorování výuky tak podporuje rozvoj tři dimenzí profesionality učitele, tj. (1) profesní vidění: vidění situace podmíněné příslušností k profesi; (2) profesní vědění: souhrn poznatků a znalostí, kterými disponují příslušníci určité profese; a (3) profesní jednání: soubor akceptovaných a etablovaných praktik prováděných v rámci určité profese (podrobněji např. Janík et al., 2016, s. 12-13). V této studii se budeme věnovat profesnímu vidění studentů učitelství.

Konkrétně se zaměříme na povahu profesního vidění studentů v rámci dvou studijních programů připravujících budoucí učitele pro různé stupně škol, tj. učitele pro 1 . stupně základní školy a učitele pro 2 . stupeň základní školy a střední školy. Věříme, že nám získaná data pomohou porozumět tomu, čeho si studenti ve výuce všímají a jak o viděném přemýšlejí, a uvažovat tak o jejich dalším profesním směřování.

Po stručném vymezení konceptu profesního vidění (zejména v kontextu př́ipravného vzdělávání učitelů) se zaměříme na vlastní výzkumné šetření a formulaci z něho vyplývajících závěrů.

\section{Profesní vidění $\mathbf{v}$ přípravném vzdělávání učitelů}

O profesním vidění (professional vision) bylo již napsáno mnoho, a to v zahraničí (např. Goodwin, 1994; Sherin, 2001, 2007; van Es \& Sherin, 2002, 2006, 2010) i u nás, kde se profesnímu vidění věnují badatelé zejména na Pedagogické fakultě Masarykovy univerzity v Brně a na Pedagogické 
fakultě Univerzity Karlovy v Praze. Zabývají se jednak zkoumáním profesního vidění v př́ípravném vzdělávání učitelů (např. Minaříková, 2014; Vondrová \& Žalská, 2015), tak rozvojem profesního vidění učitelů jako podpory jejich dalšího profesního rozvoje (Janík et al., 2016; Minaříková, Janík, Uličná, \& Janík, 2015; Stehlíková, 2010).

Profesní vidění zahrnuje dva vzájemně provázané procesy. Jedná se o tzv. všímání si (noticing) neboli výběrové zaměření pozornosti (selective atention) a o uvažování založené na vědění (knowledge based reasoning), tedy uvažování nad viděným, resp. všimnutým si (Sherin, 2007). Výzkum povahy profesního vidění nám tedy umožňuje odhalit, čeho si zástupci vybrané profese, v našem případě učitelé či studenti učitelství, ve výuce (příp. na videozáznamu výuky) všímají, ale i jak o pozorovaných jevech přemýšlejí/uvažují. Profesní vidění dále ovlivňuje profesní jednání učitelů či studentů učitelství a současně je založeno na profesním vědění, tedy především na znalostech (např. na teoretickém poznání oboru) a zkušenostech (podrobněji viz Janík et al., 2016). Právě tato vzájemná provázanost jednotlivých dimenzí profesionality učitele, ale i provázanost interních procesů profesního vidění hraje významnou roli v profesním rozvoji učitelů i v jejich přípravném vzdělávání.

V posledních letech se problematice profesního vidění učitelů a budoucích učitelů věnuje velká pozornost. $V$ naší studii se zaměříme na zachycení povahy profesního vidění budoucích učitelů anglického jazyka ve vybrané etapě jejich studia, resp. přípravy k učitelství. Abychom se vyhnuli opakování, uvedeme výsledky podobně zaměřených výzkumů až v oddíle 4 , kde je budeme dávat do souvislosti s našimi výsledky.

\section{Výzkumné šetř̌ení: zaměřeno na profesní vidění studentů učitelství}

Předložená studie je součásti širšího transdidakticky zaměřeného výzkumného šetření realizovaného napříč společenskovědními, přírodovědnými a uměleckými obory v kontextu přípravy budoucích učitelů vybraných oborů. Konkrétně se jedná o výzkum profesního vidění budoucích učitelů anglického jazyka, matematiky, biologie, výtvarné výchovy a 1. stupně. Zde se budeme zabývat studenty, kteří budou kvalifikováni k výuce anglického jazyka na 1. stupni základní školy a k výuce anglického jazyka na 2 . stupni základní školy a na střední škole. 


\subsection{Cíle a výzkumné otázky}

Cílem studie je prozkoumat profesní vidění budoucích učitelů anglického jazyka. Pozornost byla tedy věnována jednak oblasti tzv. všímání si, resp. toho, jakých doménově obecných (domain-general) i doménově specifických (domain-specific), tj. oborových jevů si studenti učitelství ve výuce všímají. Dále jsme se pokusili nahlédnout do oblasti uvažování založeného na vědění, tedy jak nad identifikovanými jevy studenti přemýšlejí. Zaměřili jsme se na rozdíl povahy vybraných aspektů profesního vidění mezi studenty učitelství anglického jazyka pro 2. stupeň základní školy a střední školy (dále AJ2) a studenty učitelství pro 1. stupeň se specializací na anglický jazyk (dále AJ1).

Výzkum byl motivován snahou zodpovědět následující výzkumné otázky:

1) Jaká je struktura všímání si studentů AJ1 a AJ2 a jaký je mezi nimi rozdíl?

2) Jak studenti AJ1 a AJ2 o všimnutém uvažují a je mezi nimi rozdíl?

3) Existuje signifikantní rozdíl mezi studenty AJ1 a AJ2? Pokud ano, jaký?

První výzkumná otázka cílila na strukturu všímání si studentů učitelství, konkrétně jsme se snažili porozumět tomu, koho a čeho si studenti ve výuce všímají. Druhá výzkumná otázka se zaměřila na to, jak o identifikovaných jevech studenti přemýšlejí/uvažují. Odpovědi na první a druhou výzkumnou otázku nám tedy pomohly zachytit povahu vybraných aspektů profesního vidění studentů učitelství, a to především jejich schopnost všímat si a částečně i procesy uvažování založeného na vědění. Předmětem třetí výzkumné otázky bylo odhalit př́ípadné signifikantní rozdíly mezi studenty AJ1 a AJ2.

\subsection{Metodologie výzkumu}

\section{Výzkumný vzorek}

Výzkumu se účastnilo celkem 45 studentů učitelství, z toho 11 studentů třetího ročníku magisterského studia učitelství pro 1 . stupeň základní školy ${ }^{2}$ se specializací na anglický jazyk a 34 studentů prvního ročníku navazujícího magisterského studia učitelství anglického jazyka pro 2. stupeň základní školy a střední školu. V obou případech se jednalo o celou skupinu studující $\mathrm{v}$ daném ročníku.

2 Studenti 1. stupně si vybírají z pěti specializací, zaměřených bud' na jednu z výchov (hudební, výtvarnou, dramatickou nebo tělesnou), nebo na vyučování jednomu z cizích jazyků - v současnosti lze zvolit specializaci na anglický jazyk. Z toho důvodu je počet studentů ve zkoumaném souboru nižší. 
Studenti AJ1 studovali v prvních dvou letech studia celou škálu studijních předmětů z oblasti univerzitního základu, pedagogicko-psychologických disciplín, základi̊ studia oborů (pro oborové, resp. předmětové didaktiky). $V$ rámci specializace na anglický jazyk absolvovali studenti předměty zaměřené na praktický jazyk, lingvistiku (zejména fonetiku a fonologii), dětskou literaturu a reálie anglicky mluvících zemí. Studenti AJ2 absolvovali bakalářské studium anglického jazyka na různých vysokých školách. Nejvíce studentů (20) absolvovalo bakalářské studium na pedagogické fakultě UK. Studenti studují dvouoborové studium v kombinaci anglický jazyk a německý jazyk (11 studentů), francouzský jazyk (8), základy společenských věd (4), pedagogika (3), matematika (2), hudební výchova (2), informační technologie (1), dějepis (1). Obě skupiny studentů byly v době sběru dat před studiem obecné didaktiky a didaktiky oborové, tedy didaktiky anglického jazyka.

\section{Výběr hodiny a úkol}

Pro potřeby realizovaného výzkumného šetření jsme použili videozáznam jedné vyučovací hodiny o délce 45 minut z roku 2015. Jednalo se o výuku anglického jazyka v 8. ročníku základní školy s rozšířenou výukou cizích jazyků. Videonahrávka byla vybrána na základě své obsahové variability, jelikož je v ní dobře vidět řada obecných, ale i specificky oborových jevů (Blomberg, Stürmer, \& Seidel, 2011). ${ }^{3}$ Jedná se o autentickou výuku, jejíž obsah je pro pozorovatele dobře srozumitelný, zahrnuje jasně identifikovatelný začátek a konec, znalost dalšího kontextu tedy není nutná. Hodina je zaměřena na výuku nové gramatiky, konkrétně vztažných zájmen.

Studenti obou skupin měli za úkol zhlédnout zmiňovaný videozáznam hodiny. Pozorovali tedy stejnou vyučovací hodinu, a to z důvodu získání srovnatelných dat. Jejich úkolem byla písemná nestrukturovaná reflexe ${ }^{4}$ hodiny, jejíž rozsah nebyl stanoven. Měli napsat, co je na videozáznamu ve výuce zaujalo, co považují za důležité. Studenti byli ujištěni, že neexistují správné či špatné odpovědi a že nebudou na základě reflexe nijak hodnoceni. Na video se mohli podívat vícekrát.

3 Což bylo potvrzeno při expertní analýze hodiny, kterou provedl tým didaktiků různých oborů $\mathrm{z}$ výše uvedeného transdidaktického výzkumu.

4 Pojem reflexe je $\mathrm{v}$ textu užíván $\mathrm{v}$ obecnějším významu, a to jako rozbor výuky. $\mathrm{V}$ tomto kontextu tedy popisuje přemýšlení studentů o výuce ve smyslu vypracování písemného rozboru zhlédnuté hodiny. 
Sběr dat

Sběr dat proběhl v zimním semestru 2015, konkrétně v prvním týdnu v rámci předmětů zaměřených na základy didaktiky anglického jazyka, tj. první didaktiky anglického jazyka v rámci studia. Studenti zpracovali reflexe jako domácí úkol a odeslali je vyučující e-mailem. Obdrženo a analyzováno bylo celkem 45 reflexí, nejkratší sestávala z 1732 znaků (včetně mezer), nejdelší z 3817 znaků (včetně mezer). 0 zhlédnuté hodině se na seminářích nediskutovalo.

\section{Analýza dat}

Nestrukturované reflexe jsme podrobili deduktivní obsahové analýze. Reflexe byly strukturovány do konkrétních jednotek analýzy, které byly tvořeny výroky studentů nesoucími jednotnou myšlenku, tzv. idea units. Jednotkami analýzy byly zpravidla věty, někde však i jen jedna z vět souvětí, pokud se každá z vět souvětí vztahovala napřs. k jinému aktérovi. Například následující výrok studenta byl rozdělen na dvě jednotky analýzy, tj. učitel a žák: Učitelka je přirozená a použivá humor, studenti na ni velice dobře reagují. Rozdělování reflexí na jednotky analýzy provedla autorka článku ve spolupráci s jedním členem výše zmíněného transdidaktického týmu.

Identifikované jednotky analýzy byly kódovány kategoriálním systémem dle van Esové a Sherinové (2010; vlastní překlad viz tabulka 1). Tento systém byl vybrán proto, že je $\mathrm{v}$ oblasti výzkumu profesního vidění rozšíren a slouží často i jako podklad pro tvorbu vlastních kategoriálních systémů (např Santagata \& Yeh, 2014).

Tabulka 1

Kategoriální systém

\begin{tabular}{lllll}
\hline Oblast & Aktér & Téma & Přístup & $\begin{array}{l}\text { Míra } \\
\text { konkrétnosti }\end{array}$ \\
\hline \multirow{4}{*}{ Kategorie } & Učitel & Obor a oborová didaktika & Popis & Konkrétní \\
& Pozorovatel videa & Klima & Hodnocení & Obecné \\
& Tvůrce kurikula & Řízení třídy & Interpretace & \\
& Jiné & Jiné & & \\
\hline
\end{tabular}


Oblast Aktér se zaměřuje na to, koho či čeho si studenti ve svých výpovědích všímají. Kromě učitele a žáka (příp. žáků) jím může být též tzv. tvưrce kurikula (curriculum designer). Tato kategorie zahrnuje osobu, která je tvůrcem materiálů využitých ve výuce, např. učební úlohy v učebnici. Kódovány jsou rovněž výroky studentů odkazující na pozorovatele videa (self), např. když studenti poukazují na vlastní učitelské či žákovské zkušenosti.

Oblast Téma zahrnuje kategorii obor a oborová didaktika, tedy konkrétní oborové obsahy a koncepty spojené s lingvistikou, resp. jazykem a jeho výukou. Kategorie pedagogika odkazuje k procesům vyučování a učení, tedy strategiím a technikám výuky obecně bez oborového obsahu. Klima zahrnuje sociální klima třídy, komunikaci mezi jednotlivými aktéry a motivaci. Kategorie řízení tř́ídy se týká organizace činností ve třídě, chování žákủ, disciplíny, technického uspořádání učebny apod.

Oblast Přístup odkazuje ke způsobu, jakým student k viděnému přistupuje, resp. jak o viděném uvažuje. Kategoriální systém obsahuje tři procesy, a to popis, hodnocení a interpretaci. $\mathrm{V}$ rámci popisu viděného studenti jednoduše referují o tom, co na videozáznamu výuky vidí. Hodnocení zahrnuje jak pozitivní, tak negativní subjektivní zhodnocení viděného, příp. návrh, jak by něco mohlo či mělo být děláno jinak (tzv. alteraci). Interpretace propojuje viděné s teorií (i naivní subjektivní teorií) či s vlastní zkušeností, interpretativní výroky tak směřují za hranici pozorovatelného k vysvětlením či příčinám pozorovaných aspektů.

Poslední analyzovanou oblastí je Míra konkrétnosti výroků. Oproti obecným jednotkám specifické analytické jednotky odkazují ke konkrétnímu dění ve tř́ídě, resp. ke konkrétní výukové situaci.

Kódováno bylo celkem 1254 jednotek analýzy, z toho 282 jednotek studentů AJ1 a 972 jednotek studentů AJ2. Každá jednotka analýzy byla kódována jednou kategorií z každé ze čtyř výše uvedených oblastí.

Data byla kódována třemi nezávislými kódovateli. Po fázi slad’ování, kdy se výzkumníci opakovaně setkávali, ladili způsob kódování u několika reflexí a upřesňovali kódovací manuál původně připravený pomocí prací van Esové a Sherinové (viz výše), nakódovali všechny reflexe. Každá reflexe tak byla kódována třikrát. Následně bylo pro každý z kódů učiněno rozhodnutí. Pokud se pro danou jednotku shodli dva až tři kódovatelé, byl vybrán jejich kód. Výsledná shoda byla velmi dobrá - všichni tři kódovatelé se shodli v $75 \%$ 
případů. Pokud byla nějaká jednotka kódována třikrát jiným kódem, pak se trojice kódovatelů na výběru kódu dohodla.

U každého studenta bylo zjištěno procentuální zastoupení jednotlivých kategorií v každé oblasti, čímž jsme získali proměnné odpovídající každé kategorii. Tato data, která měla v porovnání mezi studenty pořadový charakter, jsme použili pro statistické vyhodnocení významnosti rozdílů mezi charakterem všímání si u obou skupin studentů. I když se teoreticky jedná o data pořadová, nejdříve bylo prověřeno testem normality, zda by nebylo možné s nimi pracovat jako s daty metrickými. Test normality (Shapiro-Wilkův test, spolu s vizuální kontrolou Q-Q grafu) naznačil, že u naprosté většiny proměnných nelze předpokládat normální rozložení dat, proto jsme s daty nadále pracovali jako s pořadovými a použili jsme neparametrický MannWhitneyův pořadový test.

Analytické jednotky kódované jako žák jsme dále podrobili další analýze s cílem zjistit povahu identifikovaného rozdílu mezi oběma skupinami studentů.

\section{Výsledky výzkumu}

V oddíle 3.1 a 3.2 se budeme věnovat výzkumné otázce 1 (nejdříve pro oblast Téma a následně Aktér), v oddíle 3.3 otázce 2 (souhrnně oblasti Př́stup i Míra konkrétnosti výroků). Zkoumání podrobíme nejen oblasti a kategorie, v rámci nichž byl identifikován statisticky významný rozdíl, ale i oblasti a kategorie, v rámci nichž bylo možno vysledovat jisté tendence. $V$ oddíle 3.4 se pak podrobněji zaměříme na kategorii žák, v rámci níž byl identifikován statisticky významný rozdíl mezi studenty AJ1 a AJ2.

Statisticky významné rozdíly $\mathrm{v}$ průměrném výskytu jednotlivých kódů mezi skupinami AJ1 a AJ2 se projevily pouze v oblasti Aktér v kategorii žák $(\mathrm{U}=270, \mathrm{z}=2,19, \mathrm{p}=0,028$, rozdíl je tedy významný na hladině $5 \%)$ a v oblasti Téma $v$ kategorii jiné $(\mathrm{U}=91, \mathrm{z}=-2,64, \mathrm{p}=0,008$, rozdíl je tedy významný na hladině $1 \%$ ). Signifikantní rozdíly mezi studenty AJ1 a AJ2 byly tudíž identifikovány pouze ve dvou oblastech, resp. kategoriích. Studenti AJ1 si více všímají toho, co dělají žáci, studenti AJ2 si v oblasti Téma významněji více všímají jiných aspektů výuky, než je obor a oborová didaktika, pedagogika, klima a řízení třídy. U ostatních kategorií se sice objevily rozdíly v procentuálním zastoupení (viz obr. 1 až 4), ovšem rozdíl nebyl statisticky významný. 


\subsection{Struktura všímání si studentů AJ1 a AJ2 a rozdíly mezi nimi: Téma}

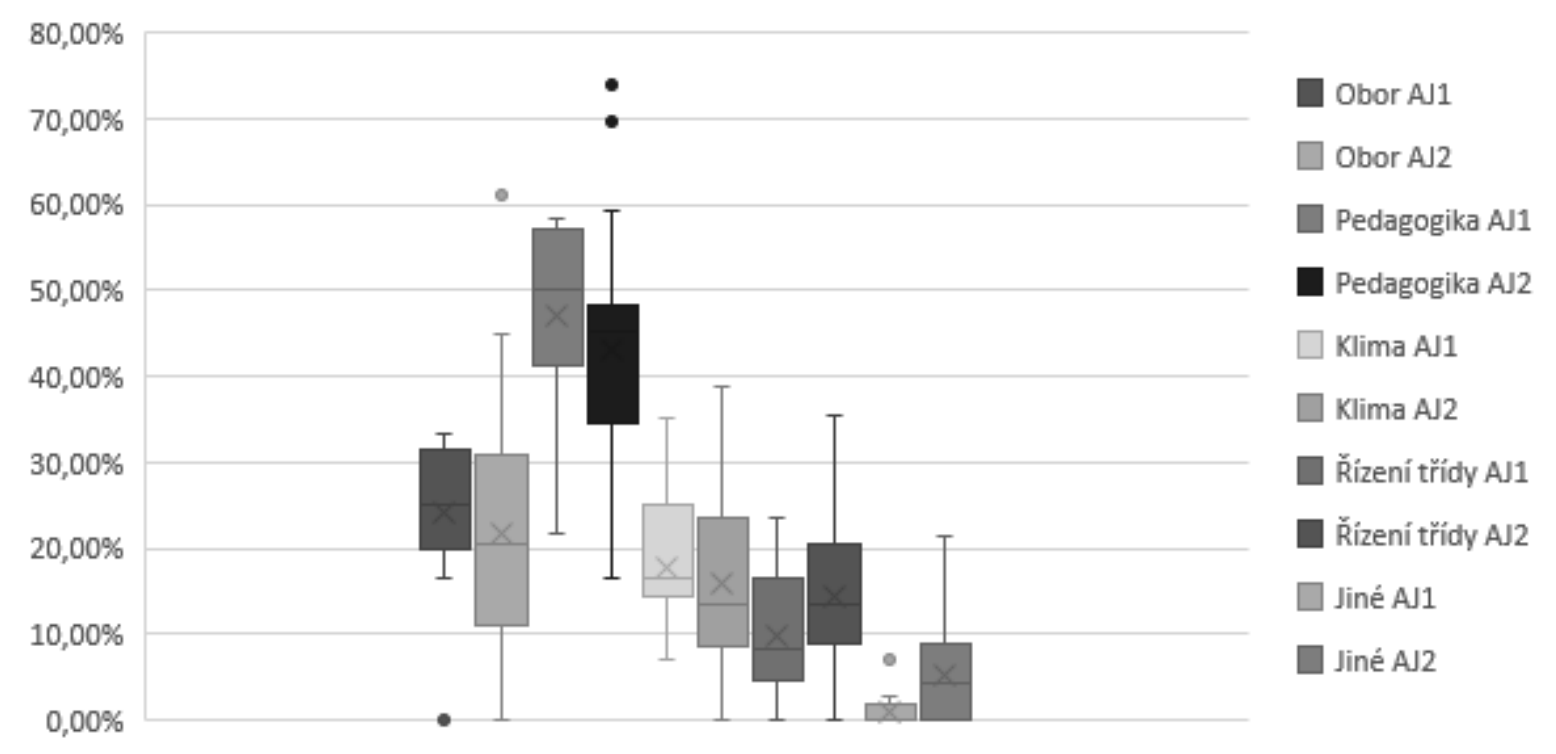

Obrázek 1. Struktura všímání si studentů AJ1 a AJ2: Téma.

Z obrázku 1 je zřejmé, že studenti obou skupin si nejčetněji všímali pedagogických a obecně didaktických jevů a méně již jevů spojených s oborem a jeho výukou. Nejméně komentovali řízení třídy (pokud nepočítáme kategorii jiné).

Jak bylo uvedeno a jak odpovídá i obrázku 1, mezi studenty AJ1 a AJ2 byl identifikován statisticky významný rozdíl $\mathrm{v}$ oblasti Téma jen pro kategorii jiné, v níž se však nacházejí výroky různého charakteru, které nelze zařadit do žádné z kategorií oblasti. V reflexích AJ2 se častěji objevily komentáře $\mathrm{k}$ celkovému hodnocení zhlédnuté hodiny, vlastních pocitů s hodinou spojených, poznámky sloužící k lepší strukturaci reflexe atd. Napřs: „I ve svém pokročilém věku také nechápu, proč musí být na tabuli neustále napsané datum. Doufám, že mi bude toto tajemství odkryto někdy v průběhu studia či praxe."

Z grafu je rovněž vidět tendence studentů AJ1 všímat si více klimatu třídy oproti jejímu řízení. To odpovídá i tomu, že učitele, s nímž je řízení přirozeně spojováno, si tito studenti všímali méně než studenti AJ2 (viz oddíl 3.2). Oproti tomu studenti AJ2 zaměřovali svou pozornost více na organizaci a řízení třídy a méně na její klima. Studenti AJ1 vykazovali silnější tendence v četnosti všímání si jak obecně pedagogických, tak oborových a oborovědidaktických jevů ve výuce než AJ2, i když ani tady, jak již bylo řečeno, nejde o statisticky významný výsledek. 
3.2 Struktura všímání si studentů AJ1 a AJ2 a rozdíly mezi nimi: Aktér Jak je vidět na obrázku 2 , studenti obou skupin si nejvíce všímali osobnosti učitele. Žáka si všímali cca o polovinu méně, avšak pouze v kategorii žák byl identifikován statisticky významný rozdíl mezi studenty AJ1 a AJ2. Studenti AJ1 si více všímali žáka/žáků a méně učitele, naopak studenti AJ2 si všímali žáků méně a více pozornosti věnovali učiteli a jeho jednání. Studenti AJ2 dále vykazovali tendenci více vztahovat viděné $\mathrm{k}$ tomu, jak by $\mathrm{v}$ daných situacích jednali sami, př́p. jak v daných situacích sami ve své př́́padné praxi jednají. Všímání si autorů kurikula či výukových aktivit bylo srovnatelné a nelze jej považovat za hojně zastoupené.

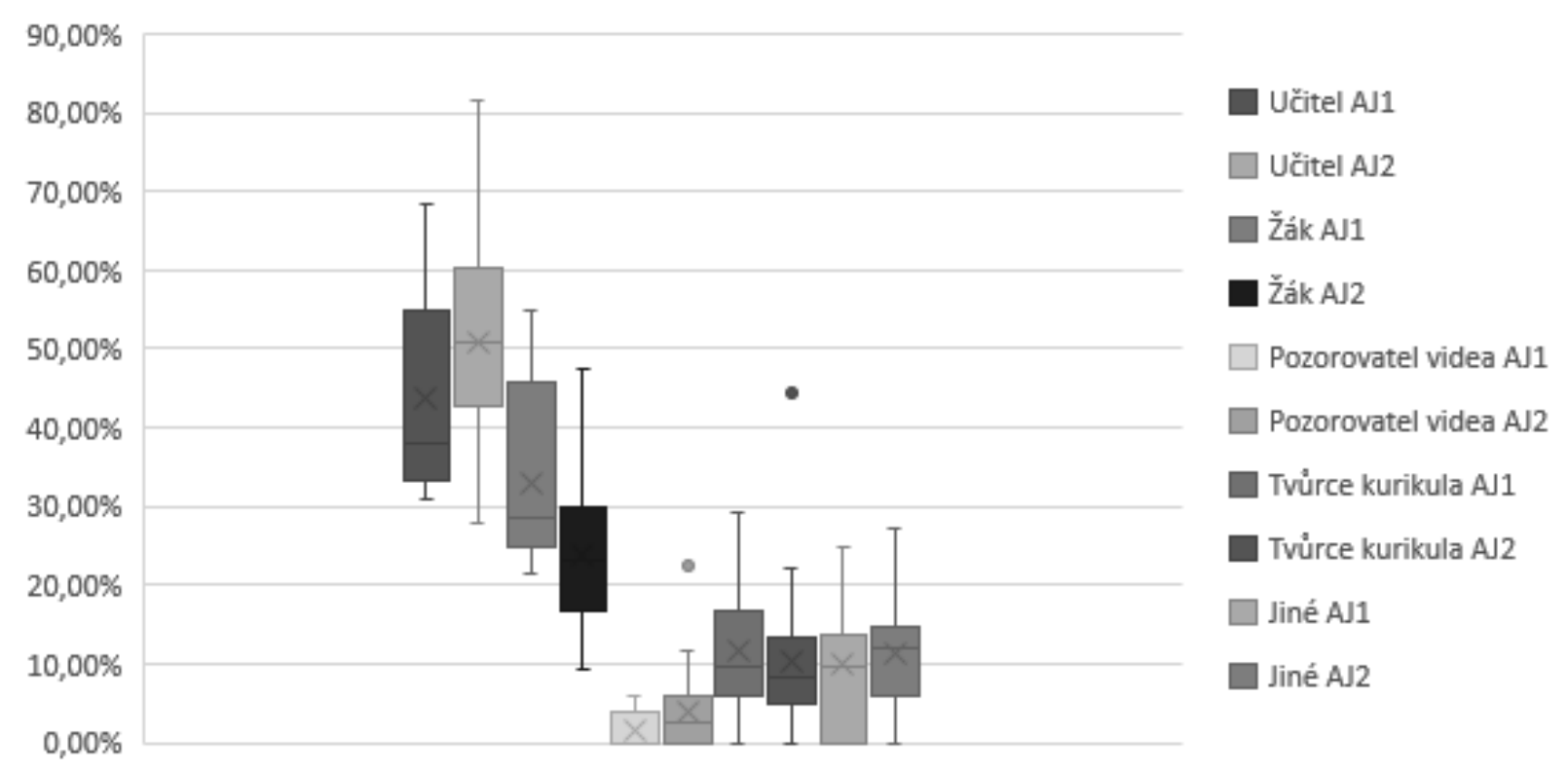

Obrázek 2. Struktura všímání si studentů AJ1 a AJ2: Aktér.

\subsection{Uvažování studentů AJ1 a AJ2 o všimnutých jevech}

Způsob uvažovaní studentů nad viděným, resp. nad tím, čeho si ve výuce všímali, zahrnuje dvě oblasti, a to Př́stup (obr. 3) a Míru konkrétnosti analyzovaného výroku (obr. 4).

V oblasti Př́stup nebyly identifikovány žádné statisticky významné rozdíly mezi studenty AJ1 a AJ2. Je zajímavé, že obě skupiny nejčetněji viděné subjektivně hodnotili, dále pak viděné interpretovali a v poslední řadě teprve popisovali. $V$ dalších dvou kategoriích byl popis implicitně obsažen, tzn. že 
studenti hodnotili či interpretovali jevy, kterých si ve výuce všimli, ovšem byl často značně nekonkrétní. Studenti AJ1 - oproti studentům AJ2 - více inklinovali k popisu viděného a méně k interpretaci, a to jak s oporou o teorii, tak o vlastní zkušenost. Zatímco byl však poměr četností výskytu popisů a interpretací u studentů AJ1 téměř stejný, u studentů AJ2 byla viditelná převaha interpretací oproti popisu.

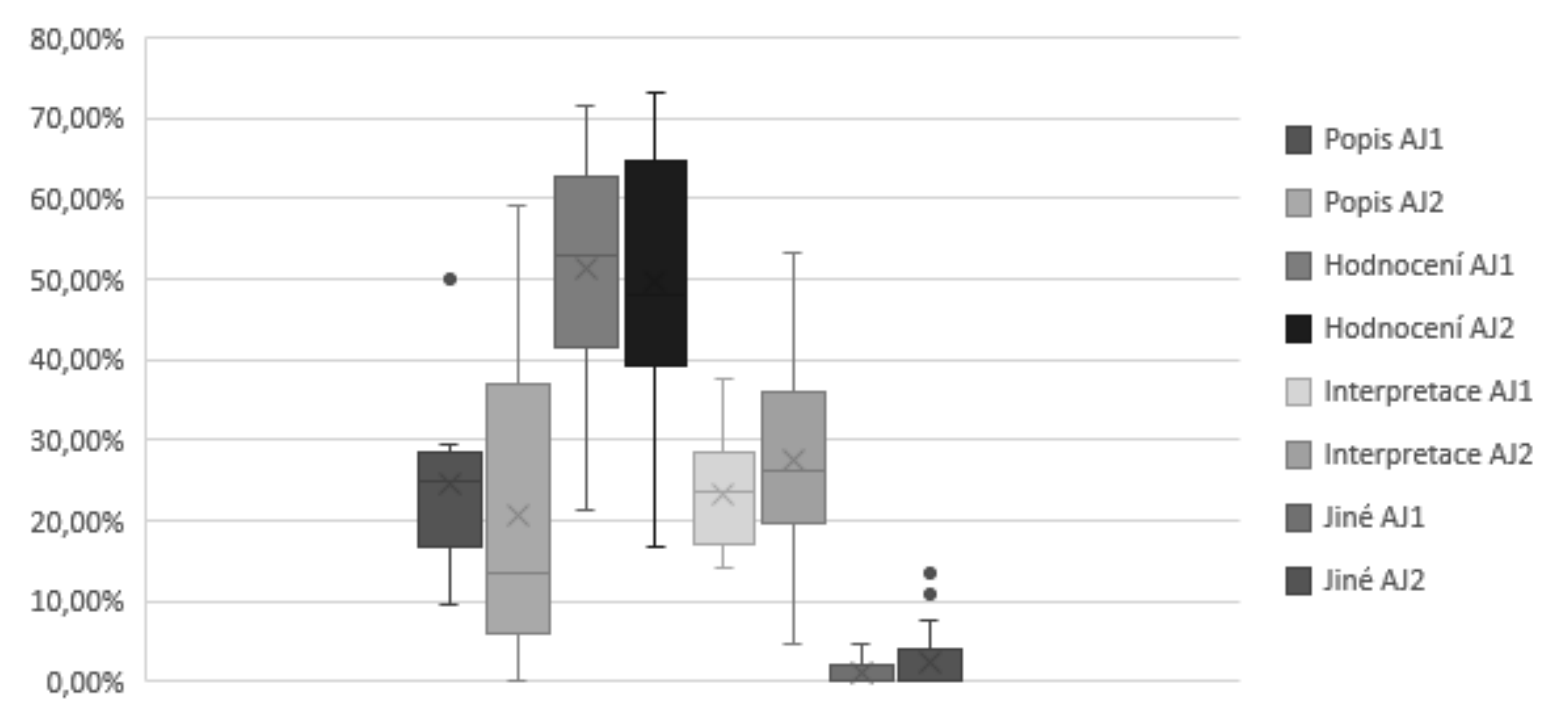

Obrázek 3. Uvažování studentů AJ1 a AJ2 o všimnutých jevech: Př́istup.

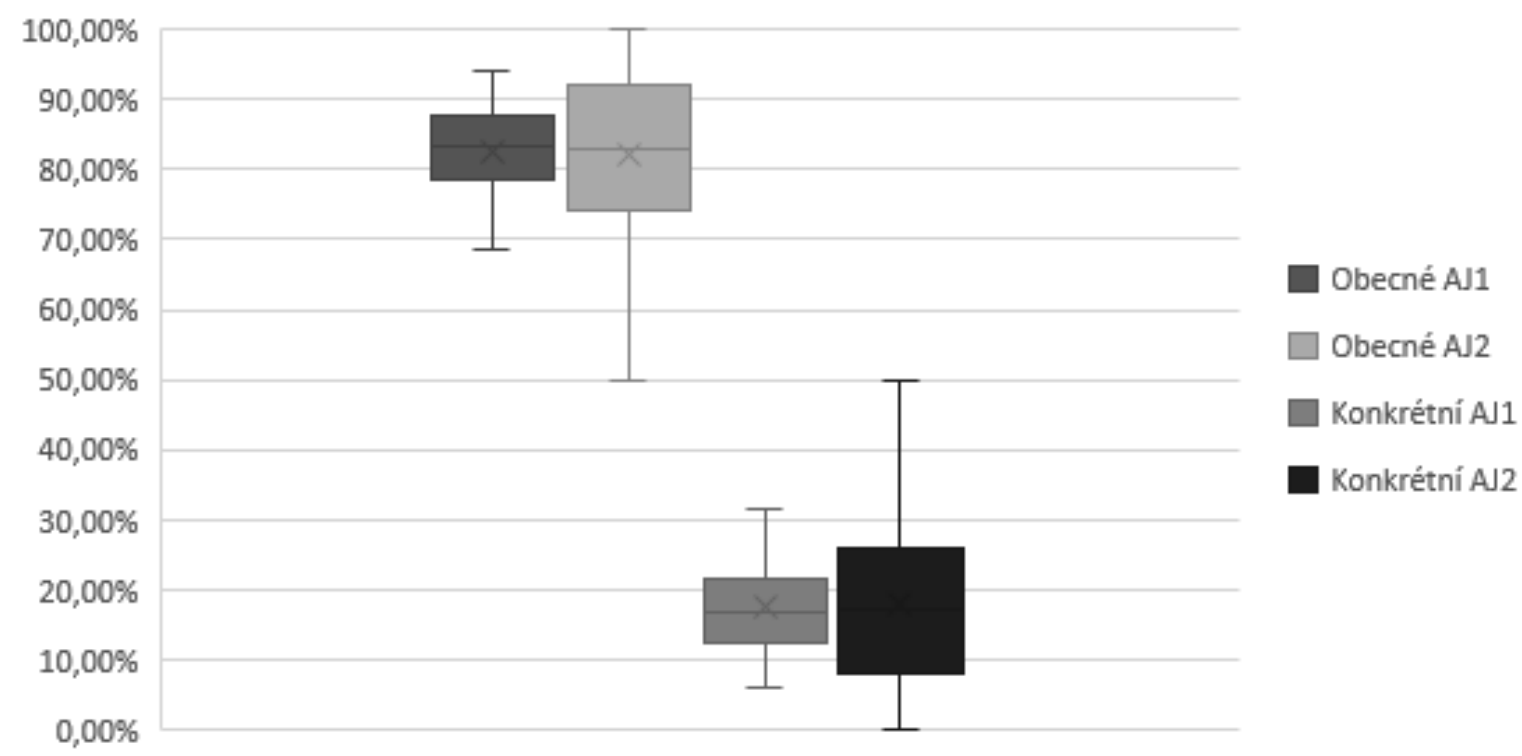

Obrázek 4. Uvažování studentů AJ1 a AJ2 o všimnutých jevech: Míra konkrétnosti. 
Výsledky v oblasti Míra konkrétnosti jsou pro studenty AJ1 a AJ2 téměř identické (obr. 4). Studenti mnohem méně popisovali konkrétní výukové situace, jejich výroky měly naopak spíše charakter obecný.

\subsection{Rozdíly mezi studenty AJ1 a AJ2: kategorie žák}

Podívejme se nyní na povahu významných rozdílů v kategorii žák u obou skupin studentů. Nejprve jsme zjištóovali, s jakými dalšími kategoriemi studenti AJ1 a AJ2 tuto kategorii spojovali, tedy jakými dalšími kategoriemi byly kódovány jednotky analýzy kódované v oblasti Aktér kategorií žák (tabulka 2). U skupiny AJ1 bylo 97 výroků kódovaných jako žák, u skupiny AJ2 to bylo 229 výroků.

Tabulka 2

Kategorie žák v kombinaci s dalšími kategoriemi

\begin{tabular}{lllllllll}
\hline Žák/Téma & $\begin{array}{l}\text { AJ1 } \\
\%\end{array}$ & $\begin{array}{l}\text { AJ2 } \\
\%\end{array}$ & Žák/Přístup & $\begin{array}{l}\text { AJ1 } \\
\%\end{array}$ & $\begin{array}{l}\text { AJ2 } \\
\%\end{array}$ & $\begin{array}{l}\text { Žák / Míra } \\
\text { konkrétnosti }\end{array}$ & $\begin{array}{l}\text { AJ1 } \\
\%\end{array}$ & $\begin{array}{l}\text { AJ2 } \\
\%\end{array}$ \\
\hline $\begin{array}{l}\text { Obor a oborová } \\
\text { didaktika }\end{array}$ & 20 & 26 & Popis & 36 & 33 & Konkrétní & 19 & 17 \\
$\begin{array}{l}\text { Pedagogika } \\
\text { Klima }\end{array}$ & 46 & 44 & Hodnocení & 37 & 31 & Obecné & 81 & 83 \\
Ř́zení třídy & 26 & 20 & Interpretace & 27 & 36 & & & \\
\hline
\end{tabular}

Pozn.: V kombinacích kódů nepracujeme s kategorií jiné. Z toho důvodu nečiní celek za jednotlivé oblasti $100 \%$.

Poměrné zastoupení jednotlivých kategorií v kombinaci s kategorií žák bylo ve většině př́ípadů stejné jako v rámci celku (napřs studenti AJ1 četněji popisovali viděné, a to jak v rámci celého výzkumného souboru, tak ve výrocích kódovaných kategorií žák). Výjimku tvoří kategorie obor a oborová didaktika z oblasti Téma. $\mathrm{V}$ rámci celku si oborových a oborovědidaktických aspektů výuky všímali častěji studenti AJ1, oproti tomu v kombinaci s kategorií žák si jich všímali více studenti AJ2.

Přestože kromě kategorie obor a oborová didaktika zůstaly poměry četností výskytu u všech dalších kategorií v kombinaci s kategorií žák stejné jako $\mathrm{v}$ rámci celku, lze $\mathrm{v}$ porovnání dat $\mathrm{v}$ tabulce 2 a obrázcích 1 a 3 identifikovat jisté posuny, resp. zvýšení či snížení četnosti výskytu vybraných kategorií. $\mathrm{V}$ rámci oblasti Téma se jednalo především o kategorii klima. 
Ve výrocích studentů AJ1 bylo obecně klima třídy zastoupeno více (viz obrázek 1: cca o $2 \%$ ). Nahlédneme-li však kategorii klima tř́́dy pouze ve vztahu ke kategorii žák, ještě výrazněji (viz tabulka 2: cca o $6 \%$ ) vystoupí ohled na žáky a jejich potřeby u studentů AJ1. V oblasti Přístup byl opět poměr četnosti výskytu kategorií v kombinaci s kategorií žák u studentů AJ1 i AJ2 stejný jako $\mathrm{v}$ rámci celku. $\mathrm{V}$ popisech viděného nebyly identifikovány téměř žádné rozdíly, a to ani v kvantitě (tj. četnosti) ani kvalitě (tj. povaze) výroků. Výrazné rozdíly mezi studenty AJ1 a AJ2 se vyskytly v oblasti všímání si žáka v kombinaci s hodnocením a interpretací. Zatímco ve výsledcích za všechny kategorie byl rozdíl mezi studenty AJ1 a AJ2 v kategorii hodnocení zanedbatelný (cca 1,5 \%), ve spojení s kategorií žák vzrostla četnost výskytu hodnotících výroků u skupiny studentů AJ1 (cca 6 \%). Oproti tomu studenti AJ2 kategorii žák více interpretovali (cca $10 \%$ ) ve srovnání s interpretacemi užitými v celku (cca $4 \%$ ).

\section{$4 \quad$ Interpretace výsledků}

Výše uvedená výzkumná zjištění poskytla data nabízející nejen vhled do povahy profesního vidění studentů AJ1 a AJ2, ale i do rozdílů mezi nimi.

\section{1 Čeho si studenti AJ1 a AJ2 všímají a jak o viděném uvažují?}

$\mathrm{V}$ této podkapitole interpretujeme získané výsledky ve vztahu k první a druhé výzkumné otázce, tj. jakého aktéra a tématu si studenti ve výuce všímají a jak o viděném uvažují.

Studenti obou skupin si nejvíce všímali učitele a jeho činnosti v hodině, což je v souladu se zjištěními u studií zkoumajících budoucí učitele jiných předmětů u nás i v zahraničí (např. Mitchel \& Marin, 2015). To je o to zajímavější, že se jedná o jiné předměty a přirozeně také o jiné hodiny, než které studenti komentovali. Bližší porovnání našich výsledků však není možné, protože jiné studie využívají jiné rámce pro analýzu dat. $Z$ tohoto hlediska je pro nás relevantní zejména studie zkoumající strukturu všímání si u budoucích českých učitelů matematiky, kteří stejně jako naši studenti neměli ještě absolvovanou obecnou a oborovou didaktiku a u nichž byl použit stejný kategoriální systém (Simpson, Vondrová, \& Žalská, rukopis). Budoucí učitelé matematiky si všímali jednotlivých aktérů $v$ téměř stejném zastoupení jako studenti našeho vzorku - AJ1 a AJ2. 
Jak vyplývá z výzkumů Fullerové (1969), která rozlišila etapy profesního rozvoje začínajících učitelů podle toho, co je pro ně v daném období dominující, orientují se začínající učitelé nejprve na osobnost učitele, tedy na sebe, teprve pak následuje orientace na pedagogickou situaci a následně na žáka. $\mathrm{V}$ našem př́padě i studenti učitelství věnovali nejvíce pozornosti osobnosti učitele. Žáka si studenti AJ1 i AJ2 všímali výrazněji méně, přičemž pouze v kategorii žák byl identifikován statisticky významný rozdíl mezi oběma skupinami. Jak jsme již uvedli, studenti AJ1 si významněji více všímali žáka/ žáků a méně učitele, naopak studenti AJ2 si všímali žáků méně a více pozornosti věnovali učiteli a jeho jednání. Uvedené může být ovlivněno rozdílným charakterem přípravného vzdělávání učitelů $\mathrm{AJ} 1$ a AJ2. V rámci př́́pravy učitelů pro 1. stupeň základní školy bývá akcentována orientace na osobnost žáka, dle Caselmanovy typologie učitele lze tedy usuzovat spíše na učitele paidotropa, který se zajímá více o osobnost žáků než o obor, snaží se porozumět potřebám žáků (Čáp \& Mareš, 2001, s. 265), a tedy i při pozorování výuky věnuje žákům více pozornosti. Rozdíl je ovšem možné vysvětlovat také tím, jací studenti se do studia učitelství obou stupňů hlásí. Studenti učitelství pro 1. stupeň si mohou toto studium vybrat právě proto, že přirozeně inklinují spíše k rozvoji žákovy osobnosti než k oboru samému.

V oblasti Téma nebyl kromě kategorie jiné nalezen v žádné z kategorií statisticky významný rozdíl mezi studenty AJ1 a AJ2. Přesto však bylo možno jednak identifikovat jisté tendence $v$ tom, čeho si studenti AJ1 všímali oproti studentům AJ2 a naopak, dále se objevily i souvislosti mezi tím, jakého aktéra a jakého tématu si studenti všímají.

Je zajímavé, že si studenti AJ1 ve výuce častěji všímali jak obecně pedagogických, tak oborových a zejména oborovědidaktických jevů, a to před studiem didaktiky anglického jazyka. Příčinou může být, že studenti AJ1 studují vzhledem ke komplexnímu charakteru jejich studia i didaktiky jiných oborů/ předmětů, lze tedy usuzovat na jistou „vytrénovanost“ ve všímání si oborovědidaktických jevů. Často se rovněž jednalo o výroky povahy spíše naivní než teoreticky oborovědidaktické, např̀. „Jednalo se o dětem známou hru, která slouží na odreagování dětí od učení se ,suchých' gramatických pravidel a přitom rozvíjí slovní zásobu a samotné vyjadřování se." Obecně si však studenti AJ1 a AJ2 všímali oborových a oborovědidaktických jevů relativně málo, což mohlo být zapříčiněno již zmíněným dosavadním absentujícím studiem oborové didaktiky a oborové praxe. Obdobné výzkumy s kvalifikovanými učiteli 
z praxe naopak poukazují právě na schopnost učitelů identifikovat ve výuce oborovědidaktické jevy (van Es \& Sherin, 2010, s. 165).

Dále byly v oblasti Téma zjištěny vztahy s oblastí Aktér. V souvislosti s již uvedenou silnější orientací studentů AJ1 na žáka/žáky bylo v této oblasti zjištěno, že si studenti AJ1 více všímali klimatu třídy. Oproti tomu studenti AJ2 zaměřovali svou pozornost více na organizaci a ř́izení třídy, a to často právě ve spojení s jednáním učitele, kterého si tato skupina studentů všímala více. Řízení třídy však bylo ve výrocích studentů AJ1 i AJ2 zastoupeno ze všech kategorií nejméně, což je v souladu se zjištěními Sonmezové a HakverdiCanové (2012, s. 150), jejichž výzkum naznačuje, že se studenti učitelství $\mathrm{v}$ počátcích práce $\mathrm{s}$ videem $\mathrm{v}$ rámci komentování výuky zaměřují na řízení tř́́dy výjimečně a pokud, tak zejména na činnosti učitele spojené s udržováním kázně ve tř́́dě.

V rámci oblasti Přístup nebyly identifikovány žádné statisticky významné rozdíly mezi studenty AJ1 a AJ2. Studenti AJ1 a AJ2 s obdobnou četností nejvíce viděné hodnotili, dále interpretovali a nejméně popisovali. Hodnocení bylo identifikováno jako nejčetněji zastoupená kategorie i ve výzkumu všímání si studentů učitelství matematiky (Mitchell \& Marin, 2014). Výsledky obdobného výzkumu studentů učitelství anglického jazyka naopak ukázaly nejvýraznější zastoupení popisu viděného, dále pak kategorii interpretace ( $v$ daném výzkumu intepretace a vysvětlení) a teprve v poslední řadě hodnocení (Minaříková, 2014, s. 767; kategoriální systém Minaříkové sestává z šesti kategorií uvažování založeném na vědění, tzn. $100 \%$ jednotek analýzy je distribuováno mezi vícero kategorií). Naopak výsledky výzkumu praktikujících učitelů v rámci počáteční fáze jejich účasti ve videoklubech byly v kategorii hodnocení (42\%) rovněž nejčetněji zastoupené (van Es \& Sherin, 2010, s. 165; využit byl stejný kategoriální systém jako v našem výzkumu). V rámci četnosti výskytu kategorie hodnocení byl v našem výzkumu rozdíl mezi studenty AJ1 a AJ2 zanedbatelný (0,5 \%). Za zmínku však stojí rozdíl mezi těmito skupinami v kategoriích popis a interpretace. Studenti AJ1 oproti studentům AJ2 více inklinovali $k$ popisu viděného a méně $k$ interpretaci, a to jak s oporou o teorii, tak o vlastní zkušenost. Zatímco poměr popisů a interpretací však byl u studentů AJ1 téměř stejný, u studentů AJ2 byl viditelný větší akcent na interpretaci oproti popisu (rozdíl činil téměř $7 \%$ ). Je možné, že užší, tj. pouze dvouoborové zaměření studentů AJ2 nabízí hlubší vhled do jednotlivých oborů. Tento vhled může jít ruku v ruce s hlubším 
uvažováním o výuce oboru, resp. předmětu. Jednotky analýzy kódované jako interpretace byly u studentů AJ2 často vztaženy $\mathrm{k}$ teorii jazyka, resp. ke gramatice, jejíž výuka byla na videu zachycena - např. „Také je občas dobré hrát s dětmi nějakou obrázkovou hru, protože si myslím, že práce s obrázky hodně napomáhá učení nových slovíček i gramatiky." Rozdíl mezi studenty AJ1 a AJ2 $\mathrm{v}$ četnosti interpretací může být rovněž zapříčiněn volbou videosekvence, jelikož studenti AJ2 sledovali výuku v jejich oborovém zaměření na 2 . stupeň ZŠ, zatímco studenti AJ1 sledovali výuku mimo jejich zaměření. Nahlížíme-li interpretace jako propojování viděného s teorií (i naivní subjektivní teorií) či s vlastní zkušeností, příp. jako vysvětlení či hledání příčin pozorovaných jevů, je možno usuzovat na jistou (pravděpodobně podvědomou) zdrženlivost studentů AJ1 při interpretování viděného. Na druhou stranu je však v tomto kontextu zajímavé, že u studentů AJ1 převažuje hodnocení viděného, tj. že nejsou v hodnocení pozorovaných jevů zdrženliví obdobně jako v jejich vysvětlování, resp. interpretaci.

Poslední analyzovanou oblastí byla Míra konkrétnosti výroků, v rámci níž byly výsledky mezi studenty AJ1 a AJ2 téměř identické, tzn. že si studenti mnohem méně všímali konkrétních výukových situací. Naše výsledky jsou v rozporu s výsledky výzkumu realizovaného van Esovou a Sherinovou (2010, s. 165), jejichž respondenti si při pozorování videí v začátku účasti ve videoklubech všímali více právě konkrétních výukových situací (62 \%). Respondenty však byli praktikující učitelé, proto je možno vysvětlovat naše výsledky právě prozatímní absencí vlastní praxe, resp. v kontextu přípravného vzdělávání absencí praxe oborové, příp. cíleného zaměřování pozornosti studentů k vybraným výukovým situacím a jejich reflexí.

\subsection{Jaký je rozdíl mezi studenty AJ1 a AJ2 v rámci výroků kódovaných kategorií žák?}

$\mathrm{V}$ této podkapitole se zaměříme na výzkumnou otázku tři, a to konkrétně na rozdíly mezi studenty AJ1 a AJ2 v rámci výroků kódovaných kategorií žák, jelikož pouze $v$ této kategorii byl identifikován mezi oběma skupinami studentů signifikantní rozdíl.

Přestože bylo kromě kategorie obor a oborová didaktika poměrné zastoupení jednotlivých kategorií v kombinaci s kategorií žák obdobné jako v rámci celku, bylo možné ve výsledcích identifikovat jisté tendence v navýšení či snížení četnosti výskytu vybraných kategorií. 
Kategorie obor a oborová didaktika si v kombinaci s kategorií žák všímali více studenti AJ2. Jak již bylo uvedeno, zdá se, že v rámci navazujícího magisterského studia, kde probíhá příprava studentů pouze ve dvou oborech, jsou studenti ve spojitosti s žákem citlivější k oborovým aspektům výuky, tj. k tomu, jak se žáci učí, př́íp. jak si osvojují vybrané jazykové jevy (studenti AJ1 věnovali ve spojení s kategorií žák více pozornosti tématu klima tríldy, viz níže). Tzv. didaktické bytí $v$ obsahu je svým charakterem z velké míry doménově specifické (viz Píšová et al., 2013, s. 34-36), je založené na znalostech oboru. Např:: „Myslím, že tato tř́́da je vybavena na to, aby minimálně hry mohly probíhat celé v anglickém jazyce. Studentům chvíli trvá, než se ,přepnou' do anglického jazyka a každé použití češtiny v tak limitovaném časové dotaci 45 minut může zbrzdit cíl udržet jejich myšlení co nejvíce v angličtině.“ $\left(\mathrm{AJ} 2^{5}\right)$. „Děti hledaly v textu vztažné věty a pak na základě těch vět vytvořily pravidlo pro užívání who, which a where.“ (AJ2). „Učební skupina sestávala z dvanácti žáků mezi třinácti a čtrnácti lety, jejichž jazyková úroveň by měla dle výběru třetího dílu učebnice English Plus odpovídat úrovni A2-B1 CEFR." (AJ2).

V rámci oblasti Téma, kategorie klima, došlo k posílení poměru výskytu identifikovaných jednotek analýzy. Nahlédneme-li tedy kategorii klima tř́́dy pouze ve vztahu ke kategorii žák, ještě výrazněji vystoupí u studentů AJ1 ohled na žáky a jejich potřeby - např:: „Reflexe slouží jak pro žáky, aby si rychle zopakovali, co se $\mathrm{v}$ dané hodině učili, tak je to velmi cenný materiál pro učitele, aby věděl, co má do př́ští hodiny změnit, na co se má zaměřit více, jaký druh práce žákům vyhovuje, jak se v hodině cítili apod.“ (AJ1). „Bylo vidět, že se všichni zapojují a nemají problém se vyjádřit." (AJ1).

Obecně lze tedy konstatovat, že studenti AJ2 byli v rámci uvažování nad žáky více zaměřeni na obor, resp. oborové aspekty výuky anglického jazyka, oproti tomu studenti AJ1 byli více orientováni na potřeby a možnosti žáků (viz didaktické bytí v obsahu vs. bytí s žákem; oborovědidaktické faktory vs. psychosociální faktory; Píšová et al., 2013, s. 46). Za zdůraznění zde stojí fakt, že tomu tak bylo již před studiem oborových didaktik, příčinu lze tudíž pravděpodobně hledat v silnější oborové zakotvenosti studentů AJ2.

V oblasti Př́stup, v kategorii hodnocení, nebyly identifikovány mezi studenty $\mathrm{AJ} 1$ a AJ2 téměř žádné rozdíly. Studenti k popisu jevů dostatečně nevyužívali

\footnotetext{
Výroky studentů jsou anonymizovány, v závorce uvádíme pouze kódy daného typu studia.
} Každý reprezentativní výrok je od jiného studenta. 
relevantní terminologii, což bylo očekávatelné u jevů oborovědidaktických, avšak již méně u jevů souvisejících s pedagogicko-psychologickou př́ípravou, kterou již v rámci studia absolvovali. Studenti obou skupin se tedy pohybovali zejména na úrovni běžného popisu viděného, resp. popisu dění ve tř́dě, přičemž v mnoha případech popisovali ty aspekty komunikační kompetence, které byly ve výuce u žáků rozvíjeny, tj. gramatiku, např:: „Před probíráním nové látky - relative pronouns - žáci měli najít věty, které tyto zájmena obsahují v textu.“ (AJ1). „Z textu mají žáci přijít na to, kdy použít who/which/ where." (AJ2).

Rozdíly mezi studenty AJ1 a AJ2 posílily v kategoriích hodnocenía interpretace.

V kategorii hodnocení došlo k výraznému navýšení četnosti výskytu u studentů AJ1. Při hlubším pohledu na povahu hodnotících výroků se ukázalo, že studenti AJ1 hodnotili především aspekty výuky spojené s žáky, jejich pocity, uspořádáním třídy ve spojení s jejím klimatem, či klima třídy samotné - např:: „Dobře řešené se zdálo uspořádání lavic. Působilo na mě daleko útulnějším dojmem, než když jsou lavice v řadách za sebou. Toto uspořádání pomohlo ve třídě vytvořit přátelštější prostředí, ve kterém se děti nemusely bát promluvit.“ (AJ1). „Měla jsem pocit, že žáci na hodiny chodí rádi a mají s paní učitelkou vřelý vztah." (AJ1). Studenti AJ2 ve svých výrocích naopak hodnotili méně, pohled na povahu jejich hodnoticích výroků ukázal, že se ve svých hodnoceních zaměřovali zejména na odlišné faktory vyučovacího procesu, a to zejména na (jednání) učitele a (výukové) aktivity, příp. na hodinu obecně (méně pak na hodnocení klimatu třídy a žáky). Tato zjištění jsou v souladu s výsledky v oblasti Téma (viz výše), v rámci níž byla u studentů AJ1 identifikována silnější orientace na žáka, u studentů AJ2 naopak převládala orientace na obor.

Oproti hodnocení studenti AJ2 více interpretovali. Při detailním pohledu na jejich interpretativní výroky lze konstatovat, že tyto nebyly nikterak hluboké, nicméně se zdá, že se studenti AJ2 snažili viděné jevy vysvětlit, najít pro ně opodstatnění. Jejich interpretace byly zřídka opřeny o oborovědidaktickou teorii, jednalo se spíše o oborovědidaktické prekoncepty, které se opírají o vlastní subjektivní zkušenost či domněnky (tzv. beliefs) o výuce. Pokud byla $\mathrm{v}$ reflexích obsažena terminologie spojená $\mathrm{s}$ oborovědidaktickými aspekty výuky, jednalo se téměř výhradně o teorie lingvistické, resp. o vybrané jazykové jevy. Většina interpretací však byla zaměřena na pedagogické, psychologické a obecně didaktické aspekty výuky, např. na učitele a dopady jeho 
jednání na žáky - chvála, podpora, aktivizace žáků, udržování pozornosti atd., na řízení třídy, př́íp. udržování pozornosti žákủ - např:: „V jednu dobu museli také vstát z lavic, což považuji za dobrý nástroj k udržení aktivity v hodině." (AJ2). „Žáci jsou viditelně motivováni, učení je baví a spolupracují s učitelem, což si myslím, že je jedna nejzásadnějších věcí dobré výuky.“ (AJ2).

Pokud tedy studenti viděné interpretovali, tj. snažili se o hlubší vhled do viděného, zdá se, že se přikláněli spíše k obecným pedagogicko-psychologickým znalostem, příp. ke znalostem oborovým. Toto je opět v souladu s fází přípravy k učitelství, ve které se studenti AJ1 i AJ2 nacházeli v době sběru dat (viz výše). Nahlédneme-li získané výsledky perspektivou Shulmanovy znalostní báze učitelství (1987), studenti se v této etapě studia mohou opírat, a také se opírali, především o znalosti obsahu (content knowledge) a znalosti obecně pedagogické (general pedagogical knowledge), nikoli však o didaktickou znalost obsahu (pedagogical content knowledge).

\section{Závěr}

$\mathrm{V}$ této studii jsme se zaměřili na profesní vidění studentů učitelství. Komentáře studentů AJ1 a AJ2 kódované dle zvoleného ověřeného kategoriálního systému nám pomohly zachytit nejen jejich schopnost všímat si ve výuce vybraných obecných i oborových jevů, ale i částečně zachytit jejich uvažování založené na vědění.

V ohnisku našeho zájmu byla snaha odhalit, zda se povaha vybraných aspektů profesního vidění liší u studentů učitelství pro 1. stupeň základní školy se specializací na anglický jazyk a u studentů učitelství anglického jazyka pro 2. stupeň základní školy a střední školy. Dále jsme se zaměřili na to, v jakých oblastech se vybrané skupiny studentů liší a jaká je povaha těchto odlišností.

Charakter dvou vybraných studijních programů se různí zejména v šíri disciplín zahrnutých do kurikula učitelské prŕípravy. Zatímco studium AJ1 zahrnuje kromě pedagogicko-psychologické přípravy i celou řadu oborů základního vzdělávání a jejich oborových či předmětových didaktik, příprava studentů AJ2 zahrnuje kromě pedagogicko-psychologického základu pouze dva aprobační obory. Oborová příprava studentů AJ2 je tedy oproti přípravě studentů AJ1 detailnější, tzn. že studenti AJ2 absolvují více lingvistických, ale i kulturně-literárních studijních předmětů. 
Na tomto místě učiníme již pouze shrnutí hlavního předmětu našeho bádání, a to rozdílu ve vybraných aspektech profesního vidění mezi studenty AJ1 a AJ2. Je zajímavé, že se charakter vybraných aspektů profesního vidění podrobených zkoumání $v$ rámci obou analyzovaných skupin studentů zásadně nelišil. Signifikantní rozdíl byl identifikován pouze v oblasti Aktér, a to v kategorii žák. Studenti AJ1 si všímali kategorie žák více než studenti AJ2. Nahlédli jsme proto kvalitu výroků kódovaných v kategorii žák v kombinaci se všemi kódy z dalších oblastí.

V kombinaci s kategorií žák došlo oproti celku k zásadní proměně četností výskytu v oblasti Téma, v kategorii obor a oborová didaktika. U studentů AJ2 se vyskytlo více všimnutých si oborových, resp. oborovědidaktických jevů. V oblasti Téma pak došlo ještě k posílení četnosti výskytu kategorie klima, a to naopak u studentů AJ1. Tyto dvě protichůdné tendence jsme interpretovali jako svým způsobem logické, a to hlubším zaměřením studentů AJ2 na obor, resp. obsah výuky, a oproti tomu silnější orientací studentů AJ1 na žáky a s tím spojené klima třídy.

V oblasti uvažování nad viděným bylo v kombinaci s kategorií žák opět identifikováno pouze posílení četnosti výskytu oproti celku, a to ve dvou kategoriích. $\mathrm{V}$ rámci hodnocení viděného došlo k posílení četnosti výskytu této kategorie u studentů AJ1, v rámci interpretace viděného pak došlo k posílení četnosti výskytu této kategorie u studentů AJ2. Je tedy zřejmé, že studenti AJ1 častěji hodnotili aspekty výuky spojené s žáky, eventuálně s konkrétním žákem. Studenti AJ2 pak výroky zaměřené na žáka častěji interpretovali, více uvažovali o tom, jak se žáci jazyk učí, případně jak si jej osvojují atd. Interpretace byly opřeny především o oborové, pedagogicko-psychologické a obecně didaktické znalosti, dále pak se v rámci interpretací objevily u studentů AJ2 oborovědidaktické prekoncepty ve formě subjektivních koncepcí či teorií opírajících se o vlastní zkušenosti či o to, čemu studenti o výuce anglickému jazyku věří.

Výsledky výzkumu nabízejí prostor pro další navazující výzkumná šetření. V souvislosti s limity realizovaného výzkumného šetření, a to relativně nízkém počtu respondentů, plánujeme výzkumné šetření opakovat s cílem porovnat výsledky v datových souborech ve dvou rozdílných časových sběrech, avšak u studentů ve stejné fázi studia. Dále by bylo zajímavé podrobit kvalitativní analýze všechny identifikované kategorie a jejich kombinace, ne pouze ty kategorie, v rámci nichž byl identifikován statisticky významný rozdíl. 
Četnost výskytu, tedy kvantitativní data, nemá přímý vliv na charakter výpovědí, tato doplňková analýza by nám tudíž poskytla hlubší vhled do charakteru výroků $v$ rámci jednotlivých kategorií. $V$ neposlední řadě pak plánujeme sběr dat u stejné kohorty studentů AJ1 i AJ2 v závěru jejich studia učitelství, tj. po absolvování oborovědidakticky zaměřených studijních předmětů $\mathrm{s}$ cílem zachytit posun $\mathrm{v}$ povaze vybraných aspektů profesního vidění $\mathrm{v}$ rámci studia a vliv rozvoje oborovědidaktického myšlení studentů a oborové praxe. Věříme, že toto porovnání dat před a po oborovědidaktické intervenci v rámci studia nám nabídne hodnotná data k úvahám nad tím, jak koncipovat (nejen) oborovědidaktickou přípravu budoucích učitelů.

\section{Literatura}

Blomberg, G., Stürmer, K., \& Seidel, T. (2011). How pre-service teachers observe teaching on video: Effects of viewers' teaching subjects and the subject of the video. Teaching and Teacher Education, 27(7), 1131-1140.

Čáp, J., \& Mareš, J. (2001). Psychologie pro učitele. Praha: Portál.

Fuller, F. F. (1969). Concerns of teachers: A developmental conceptualization. American Educational Research Journal, 6, 207-226.

Goodwin, C. (1994). Professional vision. American Anthropologist, 96(3), 606-633.

Janík, T., Minaříková, E., et al. (2011). Video v učitelském vzdělávání: teoretická východiska, aplikace, výzkum. Brno: Paido.

Janík, T., Minaříková, E., Píšová, M., Uličná, K., \& Janík, M. (2016). Profesní vidění učitelů a jeho rozvíjení prostřednictvím videoklubů. Brno: Masarykova univerzita.

Minaříková, E. (2014). Profesní vidění studentů učitelství anglického jazyka: jak vidí studenti výukové situace zachycené na videu? Pedagogická orientace, 24(5), 753-777.

Minaříková, E., Janík, T., Uličná, K., \& Janík, M. (2015, záŕí). Videokluby jako forma profesního vzdělávání. Příspěvek prezentovaný na Výroční konferenci České pedagogické společnosti, České Budějovice.

Mitchell, R. N., \& Marin, K. A. (2014). Examining the use of a structured analysis framework to support prospective teacher noticing. Journal of Mathematics Teacher Education, 17(1), 37-60.

Píšová, M., Hanušová, S., Kostková, K., Janíková, V., Najvar, P., \& Tůma, F. (2013). Učitel expert: jeho charakteristiky a determinanty profesního rozvoje (na pozadí výuky cizích jazyků). Brno: Masarykova univerzita.

Santagata, R., \& Yeh, C. (2014). Learning to teach mathematics and to analyze teaching effectiveness: Evidence from a video- and practice-based approach. Journal of Mathematics Teacher Education, 17(6), 491-514.

Sherin, M. G. (2001). Developing a professional vision of classroom events. In T. Wood, B. S. Nelson, \& J. Warfield (Eds.), Beyond classical pedagogy: Teaching elementary school mathematics (s. 75-93). Hillsdale: Erlbaum. 
Sherin, M. G. (2007). The development of teachers' professional vision in video clubs. In R. Goldman, R. Pea, B. Barron, \& S. J. Derry (Eds.), Video research in the learning sciences (s. 383-396). London: Lawrence Erlbaum Associates Publishers.

Shulman, L. B. (1987). Knowledge and teaching: Foundations of the new reform. Harvard Educational Review, 57(1), 1-22.

Sonmez, D., \& Hakverdi-Can, M. (2012). Videos as an instructional tool in pre-service science teacher education. Egitim Arastirmalarl-Eurasian Journal of Educational Research, 46, 141-158.

Stehlíková, N. (2010). Interpretace některých didakticko-matematických jevů u studentů učitelství a u učitelů matematiky. Pedagogika, 60(3-4), 303-313.

van Es, E. A., \& Sherin, M. G. (2002). Learning to notice: Scaffolding new teachers' interpretations of classroom interactions. Journal of Technology and Teacher Education, 10(4), 571-596.

van Es, E. A., \& Sherin, M. G. (2006). How different video club designs support teachers in „learning to notice“. Journal of Computing in Teacher Education, 22(4), 125-135.

van Es, E. A., \& Sherin, M. G. (2010). The influence of videoclubs in teachers' thinking and practice. Journal of Mathematics Teacher Education, 113(2), 55-176.

Vondrová, N., \& Žalská, J. (2015). Ability to notice mathematics specific phenomena: What exactly do student teachers attend to? Orbis scholae, 9(2), 77-101.

\section{Autor}

PhDr. Klára Uličná, Ph.D., Univerzita Karlova, Pedagogická fakulta, Katedra anglického jazyka a literatury, Celetná 13, 11000 Praha 1, e-mail: klara.ulicna@pedf.cuni.cz

\section{To see or not to see: Professional vision of future English language teachers and of future elementary teachers with specialisation in English}

Abstract: The aim of the empirical study is to investigate future English language teachers' professional vision. Attention will be paid mainly to the area of so called ability to notice, i.e. which domain general as well as domain specific phenomena student teachers notice. Furthermore we try to investigate the area of knowledge-based reasoning, i.e. to uncover how they think about the identified phenomena. We shall focus on the differences in the nature of selected aspects of professional vision between future English language teachers of elementary and secondary level. In the first part of the study, the concept of professional vision in the context of pre-service teacher education will be defined. Next part is devoted to the research itself, i.e. content analysis of unstructured reflections of students written after observing a video of English language teaching at a lower-secondary school. 
The findings of the study suggest that the statistically significant difference between future English teachers for secondary schools (AJ2) and future English language teachers for elementary schools (AJ1) can only be identified in the students' ability to notice the category pupil. This category is consequently analysed with the aim to find out in which aspects do the two research groups differ. The outcomes show that the main differences lie in the area of noticing the content, i.e. subject, and subject didactics, i.e. English language teaching methodology (AJ2) and classroom climate (AJ1). Moreover, in the area of knowledge-based reasoning they differ in the category evaluation (AJ1) and interpretation (AJ2).

Keywords: professional vision, noticing, knowledge based reasoning, pre-service English language teacher education, video

Strouhal, M., \& Štech, S. (Eds.). (2017). Vzdělávánía dnešek. Praha: Karolinum.

Monografie představuje texty českých a slovenských VŠ učitelů a badatelů v oblasti pedagogiky, psychologie, sociologie a filosofie výchovy, kteř́i se zabývají otázkami teorie vzdělání. Je rozvržena do tří částí, tematizujících problémy vzdělanosti z různých perspektiv a sledujících specifické logiky, rozpory a otázky těchto problémů. Zahrnuje perspektivy a texty (1) historické, (2) metodologické a filosofické a (3) texty se sociopolitickým přesahem zaměřené $\mathrm{k}$ problémům ideologizace soudobých konceptů vzdělání. Konkrétně jsou v knize řešena tato témata: historické předobrazy soudobých problémů $\mathrm{v}$ teorii vzdělání (spory Chlup - Př́hoda v české meziválečné pedagogice); Komenského obraz světa vzdělanců, jeho atributy a kritika; fenomeno-logická analýza soudobých koncepcí vzdělání v kontextu filosofie přirozeného světa; úloha metafor v pedagogickém diskursu a chybějící metafora ideje vzdělanosti; ideové a organizační změny v řízení univerzit a v podobách univerzitního vzdělávání pod vlivem neoliberálních tlaků; akademické cíle základního vzdělávání; školské reformy a jejich ideologizace; problematika kulturního relativismu ve vzdělávání. 